\title{
8. Sınıf Öğrencilerine Yönelik Fen-Matematik Temalı Bilim Kampının Değerlendirilmesi: "Gelin Tanış Olalım; Fen ve Matematiği Eğlenceli Kılalım!" Projesi ${ }^{1}$
}

\author{
DOI: 10.26466/opus.635705
}

\author{
*

\section{Cihat Abdioğlu* - Elif Yılmaz** - Mustafa Çevik***} \\ * Doç. Dr., Karamanoğlu Mehmetbey Üniversitesi, Eğitim Fakültesi, Karaman \\ E-Posta: cabdioglu@kmu.edu.tr \\ ORCID: 0000-0002-7874-2392 \\ ${ }^{* *}$ Dr. Öğr. Üyesi, Karamanoğlu Mehmetbey Üniversitesi, Eğitim Fakültesi, Karaman \\ E-Posta: elifyilmaz@kmu.edu.tr \\ ORCID: 0000-0002-1364-6359 \\ *** Doç. Dr., Karamanoğlu Mehmetbey Üniversitesi, Eğitim Fakültesi, Karaman \\ E-Posta: mustafacevik@kmu.edu.tr \\ ORCID: 0000-0001-5064-6983
}

\section{Öz}

Bu araştırmada, 8. stmı öğrencilerine yönelik TÜBİTAK tarafından 4004 - Doğa Eğitimi ve Bilim Okulları Projeleri kapsamında desteklenen "Gelin Tanış Olalım; Fen ve Matematiği Eğlenceli Kılalım!" projesinin değerlendirilmesi amaçlanmaktadır. Araştırma karma araştırma modellerinden biri olan yakınsayan paralel karma yöntem deseninde tasarlanmıştır. Araştırmanın nicel boyutunda deneme öncesi modellerden tek grup ön test-son test deseni, nitel boyutunda ise durum çalışması kullanılmıştır. Araştırmanın iki çalışma grubu mevcuttur. Çalışma Grubu I, 2017-2018 eğitim öğretim yılında Karaman il merkezinde ve merkeze bağglı köylerdeki ortaokullarda öğrenim gören sosyo-ekonomik açıdan dezavantajl, kısıtlı eğitsel imkânlara sahip, akademik başarısı yüksek ve sekizinci sinffta öğrenim görmekte olan 26 öğrenciden oluşmaktadır. Çalışma Grubu II ise proje kapsamında eğitim faaliyetlerini yürüten farkh disiplin alanlarında uzman 8 proje eğitmeninden oluşmaktadır. Araştırmada değerlendirilmesi amaçlanan proje fen, matematik ve doğa bilimlerine yönelik olarak yaparak-yaşayarak öğrenmenin temel alındı̆̆̆ zengin öğretim yöntemleriyle tasarlanmış etkinliklerden oluşmaktadır. Beş gün ve 40 saat süren proje kapsamında veri toplama aracı olarak Kişisel Bilgi Formu, "Bilim" kavramına ilişkin zihin haritası, Öğrenci Memnuniyet Anketi, Ders Gözlem Formu ve Odak Grup Görüşme Formu kullanılmıştır. Elde edilen verilerin transkripti yapılarak analiz edilmiş ve araştırma sonucunda projenin etkililiği saptanarak alan yazındaki araştırma sonuçları ile tartışılmıştır.

Anahtar Kelimeler: Bilim Kampı, Doğa Eğitimi ve Bilim Okulları Projeleri, Fen ve Matematik Etkinlikleri, Ortaokul Öğrencileri

\footnotetext{
${ }^{1}$ Bu çalışmanın bir kısmı 28 Nisan-1 Mayıs 2018 tarihleri arasında Antalya'da düzenlenmiş olan III. INES Uluslararası Eğitim ve Sosyal Bilimler Kongresi'nde sözlü bildiri olarak sunulmuştur
} 


\title{
Evaluation of Science-Math Themed Science Camp for 8th Grade Students: The Project "Let's Meet; Let's Make Science and Mathematics Fun! "2
}

\begin{abstract}
In this research, it is aimed to evaluate the Project "Let's Meet; Let's Turn Science and Mathematics into Fun!" for grade 8 students supported by TUBITAK under the projects of 4004 - Nature Education and Science Schools. The research is designed as convergent parallel mixed method design, which is one of the mixed research models. In the quantitative aspect of the study, one group pretest-posttest design, which is one of the pre-trial models and case study was used for qualitative aspect. There are two study groups of the research. Study Group I consists of 26 eighth grade students with high academic achievement who are socio-economically disadvantaged and have limited educational opportunities and who are educated in Karaman city center and in the center-affiliated villages in the 2017-2018 educational year. Study Group II consists of 8 project trainers specializing in different disciplines that carry out training activities within the scope of the project. The project targeted to evaluate in the study consists of activities designed by using rich teaching methods on the basis of learning by doing and experience towards science, mathematics and nature sciences. Within the scope of the project that lasted for five days and forty hours, Personal Information Form, mind map for the concept of "Science", Student Satisfaction Survey, Lesson Observation Form and Focus Group Interview Form were used as data collection tools. The obtained data were analyzed by transcribing and as the result of the research it is discussed with the results of the project in the literature by determining the effectiveness of the Project
\end{abstract}

Keywords: Middle School Students, Nature Education and Science Schools Projects, Science and Mathematics Activities, Science Camp

\footnotetext{
${ }^{2}$ A part of this study was orally presented at the conference III. INES International Congress on Education and Social Sciences between 28 April-1 May 2018 in Antalya.
} 


\section{Giriş}

Son yıllarda, uluslararası düzeyde gerçekleştirilen TIMSS, PISA ve ulusal düzeyde gerçekleştirilen TEOG, YGS, LYS gibi sınavlar, ülkemizdeki öğrencilerin hem fen hem de matematik derslerindeki başarılarının istenilen seviyede olmadığını ortaya koymaktadır (MEB, 2016a; MEB, 2016b; ÖSYM, 2017). Ulusal ve uluslararası sınavlarda ortaya çkan bu sonuçların bilim eğitimine ilişkin eksikliklerden kaynaklandığı düşünülmektedir. Bu bağlamda bilim eğitiminin ön plana çıktı̆̆ fen eğitimi derslerinin günlük yaşamla ilişkilendirilmemesi (Balbağ ve Karaer, 2016), derslerin uygulamadan ziyade teorik olarak yürütülmesi (Cengiz, Uzoğlu ve Daşdemir, 2012; Tekbıyık ve Akdeniz, 2010) gibi nedenlerle öğrencilerin bu alandaki öğrenme gereksinimlerini karşılayamadığına ilişkin araştırmalar mevcuttur.

Öte yandan, fen bilimleri dersi konularının genel olarak ezbere dayalı olması, bazı kavramların günlük hayatla ilişkilendirilmesinde sorun yaşanması (Balbağ ve Karaer, 2016), derslerde görsel öğelerden yeterince faydalanılmaması ve konuların örneklendirilmemesi (Cengiz, Uzoğlu ve Daşdemir, 2012) bu dersteki başarısızlığın nedenlerinden bazıları olarak açıklanmaktadır. Zira fen eğitim ve öğretimi, yalnız okul içi değil; aynı zamanda okul dışı etkinlikleri de kapsayan, özü itibariyle gözlem ve deneye dayanan günlük yaşantımızla iç içe olan bir alandır. Bu araştırma sonuçları birlikte değerlendirildiğinde, fen bilimleri derslerinde öğrencilerin gözlem ve deney yapmalarına olanak veren, yaparak-yaşayarak ve aktif olarak derse katılacakları bir öğrenme ortamına olan ihtiyacın önemi anlaşılmaktadır.

Alanyazındaki çalışmalar ülkemizde fen eğitimi gibi matematik eğitiminin de istenilen seviyede olmadığını, öğrencilerin bu dersten genellikle başarısız olduklarını, sınavlardaki matematik ortalamalarının düşük olduğunu ve matematikten uzaklaştıklarını göstermektedir (Karadeniz ve Karadağ, 2014; Kutluca, Alpay ve Kutluca, 2015; Savaş, Taş ve Duru, 2010; Usta, 2014). Matematik dersindeki bu başarısızlığın şüphesiz birçok nedeni vardır. Matematik, öğrenciler tarafından genellikle zor, sıkıcı, karmaşık, sevilmeyen ve anlaşılmayan, uzun zaman gerektiren, öğrenmekte zorlandıkları, korktukları ve başarısız oldukları bir ders olarak kabul edilmektedir (Dursun ve Dede, 2004; Even ve Tirosh, 2002; Keklikci ve Yılmazer, 2013; Kutluca, Alpay ve Kutluca, 2015; Şengül ve Cantimer-Gerez, 2016; Yavuz, Gülmez ve Özkaral, 2016). Öğrencilerin matematiğe karşı bu gibi olumsuz tutumları ve düşük özgüvenleri 
matematikte başarısız olmalarında en önemli etkenlerden biri olarak kabul edilmektedir (Baykul, 2014).

Fen bilimleri derslerinde karşılaşılan problemlerin nedenleri arasında matematik temelli sorunlar olduğu bilinmektedir (Deveci, 2010; Howe, Nunes ve Bryant 2011). Howe, Nunes ve Bryant (2011), öğrencilerin fen konularını öğrenirken yaşadıkları zorlukların bir nedeni olarak matematik bilgisi eksikliğini ifade etmişlerdir. Dolayısıyla, matematik dersindeki başarısızlığın fen dersindeki başarıyı etkilemesi kaçınılmazdır. Bu çalışmaların yanında alan yazında fen dersinde yaşanan sorunların matematiksel kavram ve ifadelerden kaynaklandığını gösteren birçok çalışma mevcuttur (Aydın, 2011; Çavaş, 2002; Howe, Nunes ve Bryant 2011).

Alanyazında yer alan araştırma sonuçları ışığında, öğrencilerin fen bilimleri ve matematiğe karşı olan önyargılarının, eğlenceli, oyun temelli, yaparakyaşayarak öğrenme fırsatı sağlayacak öğretim tasarımları ile değiştirilebileceğine inanılmaktadır. Bunun için öğrencilerin fen ve matematiğe karşı olumlu tutumlar kazandırılmasını hedefleyen bilim kampı projeleri TÜBİTAK tarafından desteklenen ve yaygınlaşan bir alan olmuştur.

Ülkemizde son yıllarda sayıları hızla artmakta olan doğa eğitimi, bilim şenlikleri, bilim okulları gibi etkinliklerin öğrencilerin bilimsel süreç becerilerinin gelişiminde, bireylerin bilime ve bilimin doğasına bakış açları ile bilime ve fen laboratuvarına yönelik tutumlarının olumlu yönde değişiminde oldukça etkili oldukları görülmektedir (Balım, Deniş-Çeliker, Türkoğuz ve Kaçar, 2013; Birinci-Konur, Şeyihoğlu, Sezen ve Tekbıyık, 2011; Çelik, 2012; Markowitz, 2004; Tekbıyık, Şeyihoğlu, Sezen-Vekli ve Birinci-Konur, 2013). Orstein (2006)'a göre bilim okullarına ilköğretim düzeyinde katılmanın, öğrencilerin fen konularına yönelik öğrenme problemlerini baştan gidermek ve fen bilimlerine karşı tutumlarını artırmada oldukça önemlidir. Konu ile ilgili yapılan çalışmalar incelendiğinde; bu tür etkinliklerin öğrencilerin fen bilimlerine ilişkin olumlu tutum geliştirmelerinin yanında, fenle ilgili meslek seçimlerini de olumlu yönde etkilediği görülmüştür (Gibson ve Chase, 2002; Knox, Moynihan ve Markowitz, 2003; Markowitz, 2004; Prokop Tuncer, Kvasnicak, 2007).

Alan yazında bilim kamplarının etkilerine yönelik yapılan çalışmalarda, bilim kamplarını öğrencilerin yalnız fen bilgisine değil; matematiğe olan tutumlarını da olumlu yönde etkilediği görülmektedir. Konu ile ilgili yapılan çalışmalar incelendiğinde; bilim kamplarına katılan öğrencilerin matematiğe 
karşı olan ilgileri ve öğrenme konusundaki motivasyonlarının arttığı, matematiğe karşı olumlu tutumlarının ve sosyal becerilerinin geliştiği, öğrenmekten zevk aldıkları görülmüştür (Siew-Eng, Kim-Leongb ve Siew-Ching, 2010). Sözer (2013)'e göre de doğada yapılan açık hava öğrenme etkinlikleri, öğrencilere özellikle bilişsel, duyuşsal ve sosyal alanlarda çok yönlü kazanımlar sağlamaktadır. Birinci-Konur ve diğerleri (2011) tarafından yapılan 'Bir Bilim Kampı Uygulamasının Değerlendirilmesi: Gizemli Dünyanın Eğlenceli Keşfi' isimli çalışmalarında belirtildiği üzere bilim kampına katılan bazı öğrenciler fen bilimleri dersleri dışında matematik, tarih, edebiyat gibi diğer disiplinlerin de kamp programına dâhil edilmesini istemektedirler.

Türkiye'de bilim okulları ve bilim kampları projelerine bakıldığında ise proje başvuru sayısı ve desteklenen proje sayısının giderek arttığı söylenebilir (URL-2). Ne var ki alan yazın incelendiğinde bu projelerin değerlendirilmesine yönelik çalışmaların oldukça sınırlı olduğu göze çarpmaktadır. Bu konuda gerçekleştirilen bazı çalışmalar incelendiğinde; Marulcu, Saylan ve Güven' in “6. ve 7. Sınıf Öğrenciler için Gerçekleştirilen “Küçük Bilginler Bilim Okulu"nun Değerlendirilmesi”, Balım ve diğerleri (2013)'nin "Bilimin Doğaya Yansımaları Projesinin Öğrencilerin Bilimsel Süreç Becerilerine Etkisi" ile Tekbıyık ve diğerleri (2013)'nin “Aktif Öğrenmeye Dayalı Bir Yaz Bilim Kampının Öğrenciler Üzerindeki Etkilerinin İncelenmesi” ön plana çıkan araştırmalar arasındadır. Gerçekleştirilen projelerin pozitif ve negatif yönlerini ortaya koyacak çalışmalar, ileride gerçekleştirilecek projelere ş̧ık tutacaktır. Bu perspektifle bakıldığında, bu çalışmanın alan yazındaki bu eksikliğin doldurulması anlamında önem arz ettiği düşünülmektedir. Öte yandan projede sadece fen ya da matematik alanlarından biri değil; her iki alana yönelik etkinlikler birlikte tasarlanmış ve uygulanmıştır. Bu bağlamda, gerçekleştirilen projenin disipline arası bir proje olduğu söylenebilir. Alan yazın incelendiğinde, her iki derse yönelik aynı anda gerçekleştirilmiş bilim kamplarının ve dolayısıyla bu kampların değerlendirilmesine yönelik çalışmaların oldukça sınırlı olduğu göze çarpmaktadır. Çalışmamızın bu yönüyle alan yazına özgün bir değer katacağı düşünülmektedir.

Bu çalışmada, TÜBITTAK tarafından 4004 - Doğa Eğitimi ve Bilim Okulları projeleri kapsamında desteklenen "Gelin Tanış Olalım; Fen ve Matematiği Eğlenceli Kılalım" projesinin eğitmen ve öğrenci görüşleri doğrultusunda nitel ve nicel araştırma yöntemleri ile birlikte çok yönlü olarak değerlendirilmesi amaçlanmıştır. Bu amaçla projenin katılımcılar üzerindeki etkilerinin 
neler olduğunun belirlenmesi, olumlu ve olumsuz yönlerinin tespit edilmesi, katılımcıların "Bilim" kavramına bakış açılarındaki değişimin ve projeden memnuniyet düzeylerinin belirlenmesi hedeflenmiştir. Ayrıca, projede görev alan eğitmenlerle projede gerçekleştirilen etkinliklerin verimliliği ve eksik yönlerinin tespitine yönelik görüşmelerin gerçekleştirildiği bu çalışmanın ileride bu tür projeler gerçekleştirecek olan araştırmacılara rehber olması hedeflenmektedir.

\section{Yöntem}

\section{Araştırma Deseni}

Çalışma, karma araştırma modellerinden biri olan yakınsayan paralel karma yöntem deseninde tasarlanmıştır. Yakınsayan paralel karma yöntem deseninde nitel ve nicel veriler birlikte toplanmakta ancak değerlendirme ayrı ayrı yapılmaktadır. Yapılan değerlendirmenin ardından verilerin birbirini doğrulayıp doğrulamadığı kontrol edilerek yorumlanmaktadır (Creswell ve PlanoClark, 2015). Bu araştırmada da nitel ve nicel veriler birlikte toplanmış ve elde edilen veriler birlikte değerlendirilerek, gerçekleştirilen projenin eğitmen ve öğrenci görüşleri doğrultusunda değerlendirilmesi amaçlanmıştır. Araştırmanın nicel boyutunda deneme öncesi modellerden tek grup ön test-son test deseni kullanılırken, çalışmanın nitel boyutunda ise durum çalışması kullanılmıştır. Bu desende elde edilen veriler ön test - son test arasındaki puanlarda anlamlı bir fark olduğunu gösteriyorsa bu farkın yapılan müdahaleden kaynaklandığı kabul edilir (Baştürk, 2009). Durum çalışması ise kapsamlı veri setlerine yönelik zaman, yer ya da fiziksel unsurlar gibi farklı açılardan sınırlı bir sistemin derinlemesine incelenmesi olarak ifade edilmektedir (Creswell, 2016). Bu araştırmaya konu olan durum, “Gelin Tanış Olalım; Fen ve Matematiği Eğlenceli Kılalım" projesi uygulama sürecidir.

\section{Proje Katılımcı Grubu}

Projeye 2017-2018 eğitim öğretim yılında Karaman il merkezinde bir, merkeze bağlı köylerde ve beldelerde bulunan dört ortaokul olmak üzere toplam beş okulda öğrenim gören 8 . sınıf öğrencileri arasından akademik başarıları 
göz önünde bulundurularak seçilen toplam 26 öğrenci katılmıştır. Öğrencilerin seçiminde gönüllülük esas alınmış olup kız ve erkek katılımcı sayılarının birbirine yakın olmasına hassasiyet gösterilmiştir. Katılımcıların belirlenmesinde ayrıca sosyo-ekonomik açıdan dezavantajlı ve akademik başarı düzeyi yüksek olan öğrencilere öncelik tanınmıştır.

\section{Uygulama Süreci}

Proje öncesinde Karaman II Milli Eğitim Müdürlüğü ile bir görüşme gerçekleştirilmiş ve ilgili şube müdürleri, öğrencilerin seçimi için idareci, rehber öğretmenler, fen ve matematik öğretmenleriyle yapılacak görüşmeler ve öğrencilerin projeye katılmaları konusunda gerekli izinler ile birlikte imkanlar dahilinde her türlü desteğin sağlanacağının teminatı sağlanmıştır. Bu görüşmede proje hedeflerine en uygun olduğu düşünülen beş ortaokul belirlenmiş ve sonrasında bu okullarda görev yapmakta olan idareciler, rehber öğretmenler, fen ve matematik öğretmenleri ile görüşmeler gerçekleştirilerek projeye katılacak olan öğrenciler belirlenmiştir. Bu süreçte projede kullanılacak araç-gereçlerin temini, öğrencilerin ulaşımı, eğitim ortamlarının hazırlanması gibi iş ve işlemler gerçekleştirilmiş ve proje için gerekli tüm şartlar yerine getirilmiştir.

Projenin ilk günü katılımclar ve proje ekibinin katılımı ile bir toplantı düzenlenmiştir. Bu toplantıda projenin amaç ve hedeflerinden bahsedilmiş; projenin etkinlik programı hakkında katılımcılar ve eğitmenler bilgilendirilmiştir. Sonrasında katılımclara farklı gruplar arasında tanınmalarının sağlanması ve motivasyonlarının artırılması amaciyla hazırlanan eğitim materyal setleri (şapka, çanta, yaka kartları, kırtasiye malzemeleri, vb.) sunulmuştur. Proje tek dönem ve beş gün olarak tasarlanmış olup projede yaparak yaşayarak öğrenmenin temel alındığı toplam 40 saat süren çeşitli etkinlikler gerçekleştirilmiştir. Etkinlikler ağırlıklı olarak fen (fizik, kimya, biyoloji) ve matematik alanlarına yönelik olarak gerçekleştirilmiş olup ayrıntıları aşağıda sunulmuştur. 


\section{Gün}

Fen Etkinlikleri: Denge Kuralım (deneysel, atölye çalışması), Kendi Mumunu Tasarla (gözlem, sanatsal, atölye çalışması), Vücudumuzu Tanıyalım-I (gözlem, drama tekniği)

Matematik Etkinlikleri: Çarkıbilim (oyun, grup çalışması)

Diğer Etkinlikler: Tanışma oyunları (oyun, sanatsal, grup çalışması),

\section{Gün}

Fen Etkinlikleri: Termometre Yapalım (deneysel, grup çalışması), Bitkileri ve Böcekleri Tanıyalım (gözlem, arazi çalışması)

Matematik Etkinlikleri: Evrenin Matematiği (gözlem), Geogebra ile Dönüşüm Geometrisi (gözlem, oyun)

Diğer Etkinlikler: Fidan Dikimi (arazi çalışması)

\section{Gün}

Diğer Etkinlikler: Tropikal Bahçe ve Bilim Merkezi Gezisi (alan gezisi, gözlem)

\section{Gün}

Fen Etkinlikleri: Bir Buton Tasarlayalım (deneysel, atölye çalışması), Biyogaz Ünitesi Kurulumu (gözlem, grup çalışması)

Diğer Etkinlikler: Tarih ve Şehir Yolculuğu (gözlem, sanatsal faaliyet), Enerjimiz Güneşten (gözlem)

\section{Gün}

Fen Etkinlikleri: Rüzgâr Gücü (atölye çalışması), Vücudumuzu Tanıyalım-II (gözlem, drama tekniği)

Matematik Etkinlikleri: Kampüsordinat (oyun)

Diğer Etkinlikler: Tarihe Yön Veren Değerlerimiz (drama, sanat ve spor çalışması) 


\section{Çalışma Grubu}

Araştırmada iki farklı çalışma grubu mevcuttur. Bunlar; projeye katılan 8. s1nıf öğrencilerinden oluşan Çalışma Grubu I ve projede eğitmen olarak görev alan 8 akademik personelden oluşan Çalışma Grubu II'dir.

Çalışma Grubu I, 2017-2018 eğitim öğretim yılında Karaman il merkezinde ve merkeze bağlı köylerdeki ortaokullarda öğrenim gören sosyoekonomik açıdan dezavantajlı, kısıtlı eğitsel imkânlara sahip, akademik başarısı yüksek ve daha önce herhangi bir TÜBİTAK projesine katılmamış 26 sekizinci sınıf öğrencisinden oluşmuştur. Çalışma grubundaki öğrencilere ait demografik özellikler Tablo 1'de sunulmuştur.

Tablo 1. Çalışma Grubu I'de Yer Alan Katılımcıların Demografik Özelliklerine İlişkin Frekans ve Yüzde Değerleri

\begin{tabular}{|c|c|c|c|}
\hline Demografik Özellikler & & $f$ & $\%$ \\
\hline \multirow{2}{*}{ Cinsiyet } & $\mathrm{K} 1 \mathrm{z}$ & 11 & 42.3 \\
\hline & Erkek & 15 & 57.7 \\
\hline \multirow{4}{*}{ Kardeş Sayısı } & Tek çocuk & 1 & 3.8 \\
\hline & Bir kardeş & 9 & 34.6 \\
\hline & İki kardeş & 10 & 38.5 \\
\hline & Üç kardeş ve üstü & 6 & 23.1 \\
\hline \multirow{3}{*}{ Annenin Öğrenim Durumu } & İlkokul & 13 & 50.0 \\
\hline & Ortaokul & 11 & 42.3 \\
\hline & Üniversite & 2 & 7.7 \\
\hline \multirow{3}{*}{ Annenin Yaşı } & $26-33$ yaş & 4 & 15.4 \\
\hline & $34-41$ yaş & 17 & 65.4 \\
\hline & 42 yaş ve üstü & 5 & 19.2 \\
\hline \multirow{4}{*}{ Babanın Öğrenim Durumu } & İlkokul & 13 & 50.0 \\
\hline & Ortaokul & 9 & 34.6 \\
\hline & Lise & 2 & 7.7 \\
\hline & Üniversite & 2 & 7.7 \\
\hline \multirow{2}{*}{ Babanın Yaşı } & 34-41 yaş & 14 & 53.8 \\
\hline & 42 yaş ve üstü & 12 & 46.2 \\
\hline \multirow{4}{*}{ Ailenin Aylık Geliri } & 1000 TL ve altı & 1 & 3.8 \\
\hline & $1001-2000 \mathrm{TL}$ & 14 & 53.8 \\
\hline & 2001-3000 TL & 5 & 19.2 \\
\hline & 3001-4000 TL & 6 & 23.2 \\
\hline \multirow{2}{*}{ Eğitime Ulaşım } & Taşımalı & 13 & 50.0 \\
\hline & Taşımalı Olmayan & 13 & 50.0 \\
\hline
\end{tabular}


Tablo 1 incelendiğinde, araştırmaya katılan 26 öğrencinin 11'inin kı, 15'inin erkek ve öğrencilerin 1'inin tek çocuk, 9'unun bir kardeşi, 10'unun iki kardeşi, 6 'sının üç ve daha fazla kardeşi olduğu görülmektedir. Katılımcıların 13 'ünün annesi ilkokul, 11'nin annesi ortaokul ve 2'sinin annesi üniversite mezunudur. Çalışmaya katılan öğrencilerin annelerinin yaş grupları incelendiğinde 4 'ü 26-33 yaş, 17'si 34-41 yaş, 5'i 42 yaş ve üzeri aralığında olduğu tespit edilmiştir. Katılımcıların 13'ünün babası ilkokul, 9'unun babası ortaokul, 2'sinin babası lise ve 2'sinin babası ise üniversite mezunudur. Çalışmaya katılan öğrencilerin babalarının yaş grupları incelendiğinde 14'ünün 34-41 yaş, 12'sinin 42 yaş ve üzeri aralığında olduğu görülmüştür. Ailelerin aylık gelir düzeylerine bakıldığında ise 1 aile 1000 TL ve altı, 14 aile 1001-2000 TL arasında, 5 aile 2001-3000 TL arasında, 6 aile ise 3001-4000 TL arasında aylık gelire sahip oldukların ifade etmişlerdir. Öte yandan, çalışmaya katılan öğrencilerden 13 'ünün taşımalı eğitim aldığı belirlenmiştir.

Çalışma Grubu II, proje kapsamında eğitim faaliyetlerini yürüten farklı disiplin alanlarında (fizik, kimya, biyoloji, sınıf eğitimi, okul öncesi eğitim, tarih) uzman 8 proje eğitmeninden oluşmaktadır. Projedeki eğitmenlerin altısı uzmanlık alanlarında doktora eğitimlerini tamamlamış, iki eğitmen ise doktora tez aşamasındadır ve tüm eğitmenler Karamanoğlu Mehmetbey Üniversitesi'nde görev yapmaktadırlar.

\section{Veri Toplama Araçları}

Araştırma kapsamında beş veri toplama aracı kullanılmıştır. Bunlar; Kişisel Bilgi Formu, "Bilim" kavramına ilişkin zihin haritası, Öğrenci Memnuniyet Anketi, Ders Gözlem Formu ve Odak Grup Görüşme Formu'dur.

Kişisel Bilgi Formu: Araştırmacılar tarafından geliştirilen "Kişisel Bilgi Formu" ile proje katılan öğrencilerin cinsiyet, kardeş sayısı, anne-baba öğrenim durumu, anne-baba yaşı, ailenin aylık gelir düzeyi ve taşımalı eğitim durumuna ilişkin demografik verileri toplanmıştır.

"Bilim" kavramına ilişkin zihin haritası: Projenin başlangıcında zihin haritasına ilişkin bilgi verilerek her öğrenciden «bilim» kavramına ilişkin bir zihin haritası tasarlaması istenmiştir. Projenin bitiminde de öğrencilerden «bilim» kavramına ilişkin bir zihin haritası tasarlamaları istenmiştir. Ön 
test-son test olarak değerlendirilen zihin haritalarında üretilen kavram sayıları karşılaştırılmıştır.

Öğrenci Memnuniyet Anketi: Araştırmacılar tarafından geliştirilen “Öğrenci Memnuniyet Anketi" beşli likert yapıda 14 sorudan oluşmaktadır. Üç alan uzmanı tarafından yapılan değerlendirmenin ardından son şekli verilen formda, öğrenciler her soru için «hiç katılmıyorum», «katılmıyorum», «kararsızım», «katılıyorum» ve «tamamen katılıyorum» şeklinde proje sürecine yönelik bir değerlendirme yapmışlardır.

Ders Gözlem Formu: Araştırmacılar tarafından geliştirilen "Ders Gözlem Formu" proje sürecinde uygulanan etkinliklerin eğitmenler tarafından değerlendirilmesi amacıyla hazırlanan 15 sorudan oluşmaktadır. 5'li likert yapıda tasarlanan form, «hiç katılmıyorum», «katılmıyorum», «karars1zim», «katılıyorum» ve «tamamen katılıyorum» seçeneklerinden biri ile değerlendirilmektedir. Uygulanan 14 eğitim etkinliğinin ardından ders gözlem formları, proje eğitmenleri tarafından değerlendirilmiştir.

Odak Grup Görüşmesi: Projenin yürütülmesinde görev alan eğitmenlerle proje sonunda yapılan odak grup görüşmesi ile projenin uygulama sürecinde yaşanan aksaklıkların, ortaya çıkan ürünlerin ve eğitim etkinliklerinin etkililiğine ilişkin görüşlerinin alınarak projenin değerlendirilmesi amaçlanmıştır. Odak grup görüşmesi, bireylerin düşüncelerini serbestçe söyleyebileceği bir ortamda dikkatlice planlanmış bir tartı̧̧ma olarak tanımlamaktadır (Krueger'den aktaran Çokluk, Yılmaz ve Oğuz, 2011). Bu kapsamda araştırmacılar tarafından tasarlanan 7 açık uçlu soru, odak grup görüşmesinde eğitmenlere yöneltilmiş ve eğitmenlerin izinleri ile ses kaydı olarak alınan cevaplar kaydedilmiştir.

\section{Verilerin Analizi}

Çalışma kapsamında elde edilen nicel veriler transkript edilerek istatistik paket programına kaydedilmiştir. Araştırmaya katılan öğrencilerin "Bilim" kavramına ilişkin zihin haritası tekniğiyle ürettikleri kavram sayısının ön test-son test puanlarının karşılaştırılması amacıyla Wilcoxon İşa- 
retli Sıralar Testi kullanılmıştır. Bunun yanı sıra projeye katılan öğrencilerin "Öğrenci Memnuniyet Anketi"ne ve eğitmenlerin her bir etkinlik için yaptıkları değerlendirmeye yönelik Ders Gözlem Formu'na verdikleri cevaplara ilişkin frekans değerleri hesaplanmıştır.

Araştırmada odak grup görüşmesinde yedi soru sorulmuş ve soruların gruptaki her katılımcı tarafından cevaplanması istenerek tartı̧̧ma tarzında U şeklinde bir oturma planı ile yaklaşık 80-90 dakika sürmüştür. Ses kaydı alınan görüşmenin transkripsiyonu yapılmıştır. Odak grup görüşmesinde, eğitmenlere yöneltilen sorular şunlardır:

- Proje bir bütün olarak değerlendirildiğinde, sizin için neyi ifade etmektedir?

- Proje sürecinde olumlu durumları göz önüne aldığınızda neler söyleyebilirsiniz?

- Projeye yönelik gözünüze çarpan en önemli sorun nedir?

- Gerçekleştirdiğiniz etkinlikte öğretim sürecine ilişkin yaşadığınız sorun varsa açılayabilir misiniz?

- Projede düzenlenmesi ya da değiştirilmesini düşündüğünüz şeyleri sıralayabilir misiniz?

- Projenin seçilen hedef kitleye uygun olup olmadığın değerlendirebilir misiniz?

- Projeye yönelik değinmek istediğiniz başka bir husus var mıdır?

\section{Bulgular}

Bu bölümde araştırma kapsamında elde edilen bulgulara yer verilmiştir. İlk olarak araştırmaya katılan öğrencilerin "Bilim" kavramına ilişkin ürettikleri kavram sayısının ön test-son test puanlarının Wilcoxon İşaretli Sıralar Testi sonuçları Tablo 2'de sunulmuştur.

Tablo 2. Öğrencilerin "Bilim" Kavramına İlişkin Ürettikleri Kavram Sayısının Ön test-Son test Puanlarının Wilcoxon İşaretli Sıralar Testi Sonuçları

\begin{tabular}{llllll}
\hline Son test-Ön test & $\mathbf{n}$ & Siralar Ortalaması & Siralar Toplamı & $\mathbf{z}$ & $\mathbf{p}$ \\
\hline Negatif Sıra & 3 & 10.67 & 32.00 & -3.23 & $.001^{*}$ \\
Pozitif Sıra & 20 & 12.20 & 244.00 & & \\
Eşit & 3 & & & & \\
\hline${ }^{*} p<.05$ & & & &
\end{tabular}


Tablo 2 incelendiğinde, araştırmaya katılan öğrencilerin "bilim" kavramına ilişkin ürettikleri kavram sayısının projede uygulanan program öncesi ve program sonrası arasında anlamlı bir fark olduğu görülmektedir $(z=-3.23$, $\mathrm{p}<.05)$. Fark puanlarının sıra ortalaması ve toplamları dikkate alındığında gözlenen bu farkın son test lehine olduğu anlaşılmaktadır. Buna göre projeye katılan 20 öğrencinin son testte ürettikleri kavram sayının ön testten yüksek olduğu, 3 öğrencinin ürettikleri kavram sayısının farklılaşmadığı saptanmıştır. Ancak araştırmaya katılan 3 öğrencinin ise son testte ürettikleri kavram sayının ön testte ürettiklerinden daha az olduğu bulunmuştur.

Öğrencilerin "Bilim” kavramına ilişkin ön test (bkz. Şekil 1) ve son test (bkz. Şekil 2) olarak tasarladıkları zihin haritalarına bir örnek aşağıda sunulmuştur.

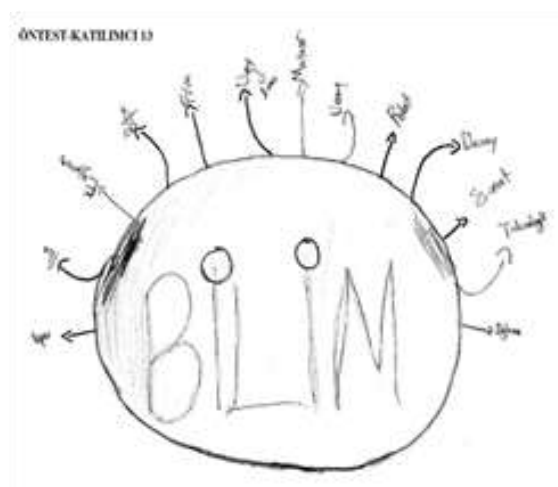

Şekil 1. Zihin Haritası-Ön test

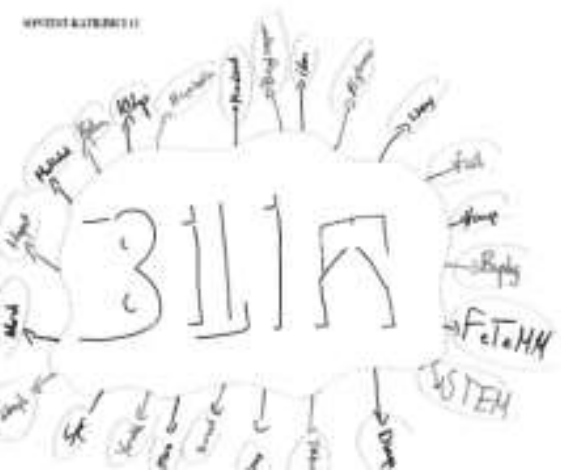

Şekil 2. Zihin Haritast-Son test

Çalışma Grubu I'i oluşturan katılımcıların Öğrenci Memnuniyet Anketi'ne verdikleri cevaplara ilişkin frekans değerleri Tablo 3'te sunulmuştur. 
Tablo 3. Katılımcıların Öğrenci Memnuniyet Anketi'ne Verdikleri Cevaplara İlişkin Frekans Değerleri

Sorular

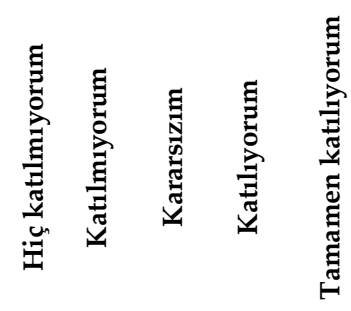

\begin{tabular}{llllll}
\hline 1. Eğitim etkinleri öğretici olmuştur. & - & - & 2 & 10 & 14 \\
2. Eğitim etkinlikleri eğlenceli olmuştur. & - & - & - & 8 & 18 \\
3. Eğitmenler, bizlere bireysel ilgi göstermişlerdir. & - & 2 & 2 & 11 & 11 \\
4. Eğitmenlerin ders anlatımları anlaşlır olmuştur. & - & - & 1 & 13 & 12 \\
5. Eğitim etkinlikleri seviyemize uygun olarak tasarlanmıştır. & 1 & 2 & 9 & 7 & 7 \\
6. Etkinlik süreleri yeterli olmuştur. & 2 & 7 & 4 & 6 & 7 \\
7. Etkinlik programı düzenli planlamıştır. & - & - & 3 & 10 & 13 \\
8. Rehberler, proje sürecinde yeterince destek sağlamıştır. & - & - & 1 & 9 & 16 \\
9. Proje ekibi ile iletişim sorunu yaşanmamıştır. & - & - & - & 8 & 18 \\
10. Karşılaşlan sorunlara proje ekibi tarafından çözüm üretilmiştir. & - & - & 3 & 6 & 17 \\
11. Önerilerimiz ve ihtiyaçlarımız dikkate alınmıştır. & - & 1 & 4 & 9 & 12 \\
12. Gezi programı öğretici olmuştur. & - & - & 2 & 9 & 15 \\
13. Gezi programı eğlenceli olmuştur. & - & 1 & 2 & 8 & 15 \\
14. Yemek ve ikramlar yeterli olmuştur. & - & - & 2 & 4 & 20 \\
\hline
\end{tabular}

Tablo 3 incelendiğinde, öğrencilerin genel olarak projeye yönelik memnuniyet düzeylerinin yüksek olduğu görülmektedir. Ancak maddeler incelendiğinde " 5 . Eğitim etkinlikleri seviyemize uygun olarak tasarlanmıştır." ve "6. Etkinlik süreleri yeterli olmuştur." maddelerine katılım oranlarının düşük olduğu görülmektedir. Buna göre öğrencilerden bazıları etkinliklerden bir bölümünün hazırbulunuşlukları açısından uygun olmadığını ifade ederken, bazı öğrenciler ise projeden duydukları memnuniyet ile ilgili olarak projenin daha uzun olmasını istemeleri nedeniyle sürenin yetersiz olduğunu söylemişlerdir.

Projedeki eğitmenlerin her bir etkinlik için yaptıkları değerlendirmeye yönelik Ders Gözlem Formu'na verdikleri cevaplara ilişkin frekans değerleri Tablo 4'te sunulmuştur. 
Tablo 4. Projedeki Eğitmenlerin Ders Gözlem Formu'na Verdikleri Cevaplara İlişkin Frekans Değerleri

Sorular

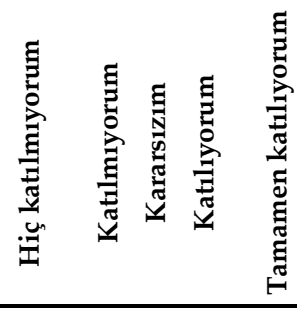

1. Öğrencilerin etkinliğe aktif katılımı sağlanmıştır.

2. Öğrenciler konuya ilişkin sorular sormuşlardır.

3. Öğrenciler sorulan sorulara yaratıcı cevaplar vermişlerdir.

4. Öğrenciler sınıf içi tartışmalara katılmışlardır.

5. Öğrenciler verilen görev ve sorumlulukları yerine getirmişlerdir.

6. Etkinliğe ayrilan süre yeterli olmuştur.

7. Etkinliğe yönelik gerekli materyaller önceden hazırlanmıştır.

8. Etkinliklerde teorik bilgiler, uygulamalar ile desteklenmiştir.

9. Etkinlikler öğrencilerin hazır bulunuşluk düzeylerine uygundur.

10. Deney ve uygulamalı etkinliklerde gerekli güvenlik önlemleri alınmıştır.

11. Etkinliğe destek veren rehberler bilgi, beceri açısından yeterli donanuma sahiptir.

12. Etkinlikte görev alan rehber sayısı yeterli olmuştur.

13. Etkinliklerin gerçekleştirildiği alanlar, uygulamalar için gerekli altyapı ve imkanlara sahiptir.

14. Proje kapsamında eğitmenlerin ve rehberlerin ihtiyaçları düşünülmüştür.

15. Etkinliklerde teknolojiyi yeterince kullanmaya imkân sağlanmıştır.

\begin{tabular}{ccccc}
- & - & - & 3 & 11 \\
- & - & - & 4 & 10 \\
- & - & - & 6 & 8 \\
- & - & 1 & 9 & 4 \\
- & - & - & 7 & 7 \\
- & - & - & 7 & 7 \\
- & - & - & 4 & 10 \\
- & - & - & 3 & 11 \\
- & - & - & 9 & 5 \\
- & - & - & 6 & 8 \\
- & - & - & 4 & 10 \\
- & - & 2 & 2 & 10 \\
- & - & - & 6 & 8 \\
- & - & - & 4 & 10 \\
- & - & - & 5 & 9 \\
\hline
\end{tabular}

Tablo 4'te projedeki eğitmenlerin her bir etkinlik için yaptıkları değerlendirmeler incelendiğinde Ders Gözlem Formu'na verdikleri cevaplar incelendiğinde dersin hazırlık, öğretim süreci ve değerlendirilmesine ilişkin olumlu algiları yüksek olduğu görülmektedir. Buna göre Ders Gözlem Formu'nun "Öğrenciler sınıf içi tartışmalara katılmışlardır." maddesine bir eğitmen kararsız olduğunu ifade ederken, iki eğitmen "Etkinlikte görev alan rehber sayısı yeterli olmuştur." maddesine kararsız olduğunu söylemişlerdir. Bu maddeler dışında eğitmenlerin genel olarak projedeki etkinliklere yönelik olumlu yargılarının yüksek olduğu söylenebilir. 
Yapılan odak görüşmesine ilişkin olarak eğitmenlerin her soruya verdikleri cevaplar transkript edilmiştir. İlk soru olan "Proje bir bütün olarak değerlendirildiğinde sizin için neyi ifade etmektedir?" sorusuna genel olarak proje kapsamında verilen eğitimin yaparak-yaşayarak öğrenmeyi desteklediği, seçilen dezavantajlı grubun projenin hedefleri açısından uygunluğu, uygulamaların eğlenceli ve kapsamlı olduğu, öğrencilere farklı bakış açları sunduğu ve ufuk açıcı olduğu ifade edilmiştir. Bu soruya ilişkin verilen cevaplardan bazıları şunlardır:

- E3. Proje çok kapsamlıydı. Hem matematik hem tarih, çok mantıklı ve yerindeydi, fizik açısından konuşmak gerekirse uygulamal konulara girilmesi çocuklar için iyi oldu, ufuklarmmı açlması konusunda ileride bir üniversiteyi tercih edeceklerinde etkili olacaktır. Aynı zamanda üniversiteyi de gelip görmeleri çocuklar için iyi olmuştur.

- $\quad$ E5. Çalışma grubu çok yerinde bir seçimdi bana göre. Çünkü biraz dezavantajl gruplar seçilmişti, bu dezavantajlı gruplarm olması yani bence çocuk uzunca bir süre ilerleyen yıllarda mutlaka görecekti bir kısmını elbet görürdü bir kısmın diye düşünüyorum. Ama bu yaşlarda görüp ufkunu bu yaşlarda açma açısından yapma başka yerleri görüp gezme kendi deyimleriyle yiyip içtikleri şeyler onlarm hayatlarında farklı bilginin yanında deneyimde vardı. Hayat deneyimi de var diye düşünüyorum. O açıdan başarılıydı diye düşünüyorum.

"Proje sürecinde olumlu durumlar göz önüne alrsanı neler söyleyebilirsiniz?" sorusuna eğitmenlerin verdikleri cevaplar incelendiğinde öğrencilerin yaşayamadıkları şeyleri deneyimledikleri ve etkinliklere odaklandıkları, projedeki eğitmen, rehber ve öğrencilerin bir ekip ruhu ile hareket ettiği, etkinliklerin dolu dolu olduğu ifade edilmiştir. Bu soruya ilişkin eğitmenler tarafindan verilen cevaplardan bazıları şunlardır:

- E1. Genel olarak izlenimim şu, burada öğrenci sıfır kazanımla gitmiş olsa bile böyle bir şeyin içinde bulunmast ileriye dönük bir gelişme bence hayatında yaşayamadikları şeyleri ilk defa yapmaları görmeleri temasta bulunmaları bu projenin en önemli başarısı bence.

- E8. Bu projenin süreci, bu projenin etkinlikleri dolu dolu olması çocuklarm etkinliklere direk girmesi, yaşayarak öğrenmeleri bu bütün etkinlikler aslında 
çocukları bağlayan faktörlerin başında geliyor. İlk gün hevesle katılabilir ama üçüncü gün bunu devam ettirmesi izleyici değil içinde kişi olmak istemesi önemli, projenin en önemli yönlerinden birisi buydu bence.

"Projeye yönelik olan gözünüze çarpan en önemli sorun nedir?" sorusuna verilen cevaplar incelendiğinde eğitmenlerden biri; proje sürecinde rehber saysınn yetersiz olduğunu, bir eğitmen ise planlama ile ilgili eksiklikleri olduğunu ifade etmiştir. Bu konuda eğitmenlerin ifadeleri şöyledir:

- E6. Kendi laboratuvarmda deney esnasinda orada personel eksikliğini hissettim. Deneyin yapılabilirliği konusunda değil. Orada şöyle bir problem oldu. Keşke sular daha öncesinden ısıtılabilmiş olsaydl, çocuklar çok bekledi orada. Bekleyince onlar kontrol etmesi de zordu.

- E8. Etkinlikleri daha önceden denemek yapmak lazım, plansizlık oldu. Santrale hepimiz ilk kez gittik, o kadar uzak olduğunu bilmiyorduk. Daha yakın bir yer seçilebilirdi.

"Gerçekleştirdiğiniz etkinlikte öğretim sürecine ilişkin yaşadığını sorun varsa açıklayabilir misiniz?" sorusuna eğitmenlerden biri önlüksüz deney yapılmaması gerektiğini ifade ederken, bir başka eğitmen düzenlenen gezi planlaması ve süresi ile ilgili yetersizlik olduğunu belirtmiştir. Bu soruya alınan örnek cevaplar şunlardır:

- E1. Laboratuvarlarımıza önlüksüz girilmez, önlük ve eldiven kullamlması görsellik açısından işin ciddiyetini açısından da önemli. Sadece yaptı̆̆ımız çalışmalarda önlük olması daha iyi olurdu. Önlük bizler için çok önemli.

- E2. Bir de hocam projenin inşallah tekrarları olursa, bilim merkezi ile ilgili de. Kelebekler vadisinde düzen çok nizamiydi. Çünkü ben çok hakimdim oraya. Ama bilim merkezinde benim hâkim olmamamdan kaynaklı bir durumdu aslinda bilim merkezine girdiğimiz andan itibaren yapilacak her şey grup şeklinde grup olarak, yönlendirmelerle yapılması bir daha ki proje yani oranın eğitmeni bendim ya orada grupları beşe, altrya bölerek çocukları, hocamm da dediği gibi eğitmenlerin de daha önceden oralarn gezerek, ben şuraya gideceğim, siz oradan çıkınca şuraya gideceksiniz şeklinde, her çocuğun her şeyi görmesi sağlanabilirdi. Biraz da geç çıknca, ben orada çok hâkim değildim. 
Sabah 9 da çıkı, akşam da 5'e yetiştireceğiz diye biraz da ondan oldu. Gezi süresi biraz daha genişletilebilir.

"Projede düzenlenmesi ya da değiştirilmesini düşündüğünüz şeyleri siralayabilir misiniz?" sorusuna verdikleri cevaplar incelendiğinde herhangi bir sorun karşısında alternatif planlar tasarlanabileceği, rehberlerin önceden etkinliklerle ilgili eğitilmesi gerektiği ve rehber seçiminde etkinlik türüne uygun alandan kişilerin tercih edilmesi gerektiği ve etkinlik takviminin sıkışık olduğu ve daha esnek bir program tasarlanabileceği belirtilmiştir. Bu kapsamda eğitmenlerin ifadelerinden bazıları şunlardır:

- E2. Takvimde verilen saatler ile sizin saatlerin arasinda biraz esneklik olması lazım. Tamam TÜBİTAK bunu istiyor ama o öyle olmayacak o belli onun bir alternatif şeyi olması lazım. Bir B planı, hatta bir C planı belirli şeyler öngörülebilir. Öngörülemeyenlerde var tabi.

- E6. Rehberlerin eğitilmesi, her ne çalışma yapılacaksa en azından iki tanesinin o konu hakkmda önceden bilgi sahibi olması bence gerçekten önemli. Çünkü çocuklarla aynı seviyede oluyorlar. Tamam belirli şeylerde hakimsiniz ama diğer bir alana geçtiğiniz zaman o çocuktan bir farkını yok ilk kez görüyorsunuz. Rehberler daha önceden eğitilirse daha iyi olur. İşleyiş daha kolay olur. Biri olmasa biri kurtarır en azindan.

"Projenin seçilen hedef kitleye uygun olup olmadığın değerlendirebilir misiniz?" sorusuna eğitmenlerin verdikleri cevaplar incelendiğinde tüm eğitmenler projenin seçilen hedef kitleye uygun olduğunu ifade etmişlerdir. Ancak bir eğitmen, gezi programında ziyaret edilen tarihi mekanlara ilişkin bilgilerin çocukların yaşına indirgenemeyeceğini belirtmiştir. Bunu şu şekilde ifade etmiştir:

- E7. Ben kendi adıma, gittiğimiz ören yerleri hakkında öğrenciye açıklamamız imkânsız gibi bir şey. Yani erken Hristiyanlik demek ne anlayabilir sadece 1800 yıl önce insanlar oymuş ancak diyebiliyoruz. Ne dersek öğrenci için anlamsız kaliyor. Gittiğimiz yerlerle ilgili bilgi çok az. 
Son olarak "Projeye yönelik değinmek istediğiniz başka bir konu var mı?" sorusuna eğitmenlerin verdikleri cevaplar incelendiğinde eğitmenler gelecekte tasarlanacak projeler için olası fikirlerini ifade etmişlerdir. Bu soruya ilişkin eğitmenler tarafından verilen cevaplardan bazıları şunlardır:

- E4. Sizlerle çalışmak çok eğlenceliydi. Hocam bir daha ki sağllklı beslenme ve bulaşıcı hastalıklar konusunda özellikle riskli kimlik bütünlüğ̈̈ oluşması için ergenlik dönemine giriyorlar çocuklar o psikolojik açısından mutlaka belli konularn eklenmesi gerekiyor.

- E8. Enerjiyi verimli kullanma alanında da grup çok uygun bir grup. Mesela geri dönüşüm, çocuk bunu öğrendiği zaman aslnda evdeki herkese bunu uygulatır. Bilim merkezinde en fazla onlar dikkatlerini çekti zaten. Geri dönüşüm işte ne kadar su gidiyor onlar acayip dikkatlerini çekti. 30 çocuktan 1 çocuk yapsa belki bir etkinlik onunla ilgili düzenlenebilir.

\section{Tartışma ve Sonuç}

Karma araştırma deseniyle gerçekleştirilen bu araştırmanın sonucunda, öğrencilerin «Bilim» kavramına ilişkin zihin haritalarında ön test ve son test olarak ürettikleri kavram sayılarının anlamlı farklılık gösterdiği saptanmıştır. Buna göre projeye katılan 20 öğrencinin son testte ürettikleri kavram sayıs1nın ön testte ürettikleri kavram sayısından fazla olduğu, 3 öğrencinin son testte ürettikleri kavramların ön test ile eşit olduğu ancak 3 öğrencinin ise son testte ürettikleri kavram sayısının ön testte ürettikleri kavram sayısından az olduğu belirlenmiş̧tir. Alan yazın incelendiğinde gerçekleştirilen doğa eğitimleri ve bilim kamplarında zihin haritalama yoluyla öğrencilerin proje boyunca edindikleri kavramları ölçen herhangi bir çalışmaya rastlanmamıştır. Lakin bilim kampları sonunda öğrencilerin bilimsel süreç becerilerinin olumlu yönde geliştiği (Balım, Deniş Çeliker, Türkoğuz ve Kaçar, 2013; Liu ve Lederman, 2002; Metin, 2009), bilime ve bilimin doğasına ilişkin olumlu tutum geliştirdikleri (Khishfe ve Abd-El-Khalick, 2002; Leblebicioğlu, Metin, Yardımcı ve Berkyürek, 2011) ve akademik başarılarının olumlu yönde arttığına (Gökler, 2012; Yazkan, 2012) ilişkin sonuçlara ulaşıldığı görülmektedir. Bu bağlamda, proje sonunda öğrencilerde meydana gelen "Bilim" e yönelik ürettikleri kavramların pozitif yöndeki artışı alanyazınla örtüştüğü söylenebilir. Palmberg ve Kuru (2000) tarafindan yapılan doğa eğitimi ve bilim 
kampı proje değerlendirme çalışması sonucunda, doğadaki deneyimlerin öğrencilerin özgüvenlerini geliştirdiği, okul dışı etkinliklere katılmaya daha istekli duruma getirdiği, daha sosyal davranışlar sergiledikleri belirtilmiştir.

Araştırmada öğrencilerin proje sonundaki memnuniyet düzeylerine ilişkin yapılan Öğrenci Memnuniyet Anketi sonuçları incelendiğinde, genel olarak öğrencilerin proje sürecine ilişkin olumlu algıya sahip oldukları söylenebilir. Bu sonuçtan hareketle öğrencilerin bilimsel aktivitelere, bilimsel bilgiye ve yine bilim insanlarına olan bakış açlarında olumlu bir değişiklik gerçekleştiği ifade edilebilir. Literatürde benzer şekilde doğa eğitimi ve bilim kamplarının sonuçlarına ilişkin yapılan bazı çalışmalarda öğrencilerin bilimsel araştırmaya karşı ilgilerinin olumlu yönde geliştiğini görmek mümkündür (Güler, 2009; Kang ve Wallace, 2004; Keleş, Uzun ve Uzun, 2010; Birinci-Konur, Şeyihoğlu, Sezen ve Tekbıyık, 2011; Markowitz, 2004). Öğrencilerin projeden memnuniyetlerine ilişkin sonuç, projede görevli eğitmenlerin de benzer söylemlerde bulunması ile desteklenmektedir. Eğitmenler, özellikle projede yaparak-yaşayarak öğrenme fırsatlarının sunulmasının ve eğlenceli bilimsel etkinliklere yer verilmesinin öğrencilerin projeye, dolayısıyla bilime olumlu bir yaklaşım sağladığını ve projeden genel olarak memnun kaldıklarını dile getirmişlerdir. Halihazırda yapılan çalışmalardan bazıları da okul kamplarının eğlenceli olduğunu ve öğrencilerin birbirleriyle devamlı iletişim halinde olduklan, böylelikle kişisel ve sosyal gelişimleri üzerinde pozitif etkiye sahip olduğu rapor edilmiştir (Çelik, 2012; Dillon vd., 2006; Lien, 2007; Smith, Steel ve Gidlow, 2010; Tatar ve Bağrıyanık, 2012; Tekbıyı, Şeyihoğlu, Sezen-Vekli ve Birinci-Konur, 2013). Bununla birlikte araştırmada, proje sonunda öğrencilerin bir bölümü, proje süresinin yeterince uzun olmadığını, projede bazı etkinliklerin seviyelerine uygun olmadığını ve proje sürecinde kendilerine fazla ilgi gösterilmediğini ifade etmişlerdir. Öğrencilerin dile getirdiği bu olumsuzlukların bir benzeri de eğitmenlerle yapılan odak grup görüşmesi sonucunda ortaya konmuştur. Eğitmenler özellikle gezi ve gözlem etkinliklerinin daha verimli olabilmesi için planlamanın daha etkin, uzun vadeli ve alternatifleri düşünülerek tasarlanması gerektiğini çünkü istenilen düzeyde gerçekleşmediğini ifade etmişlerdir. Bu sonuç, alan yazında benzer şekilde bazı doğa eğitimi ve bilim kampı projelerinde de yer almaktadır (Birinci-Konur, Şeyihoğlu, Sezen ve Tekbıyık, 2011; Oğurlu, 2016) 
Projede görev alan eğitmenlerin gerçekleştirdikleri etkinliklere ilişkin yaptıkları değerlendirmeler arasında eğitmenlerin etkinlik sürecine yönelik olarak olumlu yargılara sahip oldukları ifade edilebilir. Ancak bazı etkinlikler için rehber sayısının yetersizliği ve öğrencilerin sınıf içi tartışmalara aktif katılımlarının sınırlı kaldığı belirtilmiştir. Bu durum projeye katılan öğrencilerin bireysel ilgi gereksinimleri ile de bağdaşmaktadır. Gelecekte yapılması planlanan bilim kampı, doğa eğitimleri veya alan gezilerinde bu tarz istenmeyen olguların önüne geçilmesi için alınacak tedbirler arasında sayılabilir. Bu sonuca benzer şekilde gerçekleştirilen doğa eğitimleri ve bilim kampları gibi etkinliklerin öğrencileri öğretim ortamlarında daha aktif kıldığını belirtmektedir (Ballantyne ve Packer, 2002; Palmberg ve Kuru, 2000; Yalçın, AteşSönmezoğlu, Akın ve Sönmezoğlu, 2014). Doğada gerçekleştirilen eğitimlerde öğrencilerin daha merkezde olmasl, etkinliklerde aktif rol üstlenmesi ve özellikle sınıf içi tartışmalarda özgüven kazanmaları için sorumluluk almalarına firsatlar verilmesi önemlidir. Yine projeye katılan eğitmenler doğa eğitimleri ve bilim kamplarında bilimsel etkinliklerin yanında çevresel ve kültürel etkinliklere daha çok zaman ayrılması gerektiğini belirtmişlerdir. Bu durum alan yazında bazı araştırmalarda da rapor edilmiştir (Meydan, Bozyiğit ve Karakurt, 2012; Oğurlu, 2016). Tüm bu sonuçlardan yola çıkılarak araştırmacı ve eğitimcilere yönelik öneriler şunlardır:

- Uygulanan proje, öğrencilerin aktif katılımlarının sağlandığı deney, gözlem ve yaparak-yaşayarak öğrenmenin temel alındığı yöntemlerle gerçekleştirilmiştir. Öğrencilerin okul sürecinde aldıkları eğitimin de mümkün olduğu ölçüde farklı yöntemlerle zenginleştirilerek öğrencilere sunulması önerilebilir.

- Sınırlı bir çalışma grubu ile yürütülen bu projenin benzer nitelikte, daha büyük kitlelere yönelik olarak uygulanması sağlanabilir.

- Projede bilimsel etkinliklerin yanında kültürel etkinlikler yönelik içerik zenginleştirilebilir.

- Proje kapsamında gerçekleştirilen etkinliklerin öğrenci seviyesine uygunluğuna dikkat edilerek düzenlemeler yapılabilir. Buna ek olarak eğitim ihtiyaçlarının önceden tespiti ile öğretim tasarımlarında ekleme ve düzeltmeler yapılarak öğretim tasarımları geliştirilebilir. 


\title{
EXTENDED ABSTRACT
}

\section{Evaluation of Science-Math Themed Science Camp for 8th Grade Students: The Project "Let's Meet; Let's Make Science and Mathematics Fun! " \\ *}

\author{
Cihat Abdioğlu - Elif Yılmaz - Mustafa Çevik \\ Karamanoğlu Mehmetbey Üniversitesi
}

In this study, it is aimed to evaluate the project "Lets meet; Let's Turn Science and Mathematics in to Fun!" supported by TUBITAK under the projects of 4004 - Nature Education and Science Schools with both qualitative and quantitative research methods in versatile way. For this purpose, it is aimed to determine what the effects of the project on the participants are, to determine its positive and negative aspects, and thus to guide the researchers who will carry out such projects in the future.

The research is designed as convergent parallel mixed method design which is one of the mixed research models. In this study, qualitative and quantitative data are collected together and quantitative data play a supporting role for qualitative data. In the quantitative aspect of the study, one group pretest-posttest design, which is one of the pre-trial models and case study was used for qualitative aspect.

There are two study groups of the research. Study Group I consists of 26 eighth grade students with high academic achievement who are socio-economically disadvantaged and have limited educational opportunities and who are educated in Karaman city center and in the center-affiliated villages in the 2017-2018 educational year. Study Group II consists of 8 project trainers specializing in different disciplines (phisics, chemistry, biology, classroom education, pre-school education, history) that carry out training activities within the scope of the project.

Five data collection tools were used in the research. These are the Personal Information Form, the Mind Map for the concept of "Science", the Student Satisfaction Survey, the Lesson Observation Form and the Focus Group Interview Form. 
In the research, it was determined that the students had a meaningful difference in the mind maps of the concept of "science" in favor of the posttest of the concepts they produced as pre and post. Although there is no specific research to support this finding the researchs in the direction of showing that at the end of the science camps scientific process skills of the students have improved in the positive direction (Balım, Deniş Çeliker, Türkoğuz and Kaçar, 2013; Liu and Lederman, 2002; Metin, 2009), they have developed positive attitude towards the nature of the science (Khishfe and - Abd-El Khalick 2002; Leblebicioğlu, Metin, Yardımc and Berkyürek, 2011) and their academic achievements have been improved positively (Gökler, 2102; Yazkan, 2012) is the caracteristic of supporting the result of this research.

It was determined that the students participated in the project had a positive perception of the project process. In the same way, it is possible to come across with in some studies on the results of nature education and science camps in the literature reported that students' positive response to scientific research have been deceloped in the positive way (Güler, 2009; Kang and Wallace, 2004; Keleş vd., 2010; Konur Birinci, Şeyihoğlu, Sezen and Tekbıyık, 2011; Markowitz, 2004). Similarly, trainers have expressed that especially the opportunities towards learning by living-doing and being plenty of fun scientific activities in the project make students to have positive attitute towards the project and hence to the science and they are generally satisfied with the project. Studies in the literature support this result (Çelik, 2012; Dillon vd., 2006; Lien, 2007; Smith, Steel and Gidlow, 2010; Tatar and Bağriyanık, 2012; Tekbıyık, Şeyihoğlu, Sezen-Vekli and Birinci-Konur, 2013).

At the end of the focus group discussion with the trainers on the activities conducted by them, it was stated that the trainers generally have positive judgments but the inadequacy of the number of guides for some activities and the active participation of the students in the class discussions are limited. Again, as indicated by some of the trainers involved in the project, more time should be devoted to environmental and cultural activities as well as scientific activities in nature education and science camps. This situation has also been reported in some researches in the literatüre. 
When all these results are evaluated together it can be said that the procejct "Lets meet; Turn Science and Mathematics in to Fun!" supported by TUBITAK under the projects of 4004 - Nature Education and Science Schools achieved its objective

\section{Kaynakça / References}

Aydın, A. (2011). Fen Bilgisi öğretmenliği öğrencilerinin bazı matematik kavramlarına yönelik hatalarının ve bilgi eksiklerinin tespit edilmesi. Bahçeşehir Üniversitesi Fen Bilimleri Enstitüsü Dergisi, 13(1), 78-87.

Balbağ, M. Z., ve Karaer, G. (2016). Fen bilgisi öğretmenlerinin fen öğretiminde karşılaştıkları sorunlara yönelik öğretmen görüşleri. Eğitim ve Öğretim Araştırmaları Dergisi, 5(3), 1-11.

Balım, A. G., Deniş-Çeliker, H. D., Türkoğuz, S. ve Kaçar, S. (2013). The effect of reflections of science on nature project on students' science process skills. Journal of Research in Education and Teaching, 2(1), 149-157.

Ballantyne, R., ve Packer, J. (2002). Nature-based excursions: School students' perceptions of learning in natural environments. International Research in Geographical and Environmental Education, 11(3), 218-236.

Baştürk, R (2009). Deneme modelleri. (A. Tanrı̈öğen Edt.), Bilimsel Araşırma Yöntemleri, Ankara:Anı Yayıncilik.

Baykul, Y. (2014). Ortaokulda matematik öğretimi (5-8. Sinfflar), yeni programa uygun geliştirilmiş 2. Baskı. Ankara: Pegem Akademi Yayıncılık.

Birinci-Konur, K., Şeyihoğlu, A., Sezen, G. ve Tekbıyık, A. (2011). Bir bilim kampı uygulamasının değerlendirilmesi: gizemli dünyanın eğlenceli keşfi. Kuram ve Uygulamada Ĕ̆itim Bilimleri, 11(3), 1589-1608.

Cengiz, E., Uzoğlu, M. ve Daşdemir, İ. (2012). Öğretmenlere göre fen ve teknoloji dersindeki başarısızlık nedenleri ve çözüm önerileri. Erzincan Üniversitesi Ĕ̆itim Fakültesi Dergisi, 14(2), 393-418.

Creswell, J. W. (2016). Araştırma deseni nitel, nicel ve karma yöntem yaklaşımları, (Çev. Ed. S. B. Demir). 2. Bask1. Ankara: Eğiten Kitap.

Creswell, J. W., ve Plano-Clark, V. L. (2015). Karma yöntem araştırmaları tasarımı ve yürütülmesi.(Çev. Ed. Y. Dede ve S. B. Demir). 2. Bsm. Ankara: Anı Yayincilik. 
Çavaş, B. (2002). İlköğretim 6. ve 7. sinıflarda okutulan matematiğe dayalı fen konularında yaşanan sorunlar, matematiğin bu sorunlar içerisindeki yeri ve bu sorunlarm giderilmesinde teknolojinin rolü ve çözüm önerileri. Yayımlanmamış Yüksek Lisans Tezi. Dokuz Eylül Üniversitesi, Eğitim Bilimleri Enstitüsü, İzmir.

Çelik, İ. (2012). Bir bilim kampından notlar. TUBITTAK Bilim ve Teknik Dergisi, 538, 15-19.

Çokluk, Ö., Yılmaz, K., ve Oğuz, E. (2011). Nitel bir görüşme yöntemi: Odak grup görüşmesi. Kuramsal Eğitimbilim Dergisi, 4(1), 95-107.

Deveci, Ö. (2010). İlköğretim altıncı sinıf fen ve teknoloji dersi kuvvet ve hareket ünitesinde fen-matematik entegrasyonunun akademik başarı ve kalıcllk üzerine etkisi. Yayımlanmamış Yüksek Lisans Tezi. Çukurova Üniversitesi, Sosyal Bilimler Enstitüsü, Adana.

Dillon, J., Rickinson, M., Teamey, K., Morris, M., Choi, M. Y., Sanders, D., ve Benefield, P. (2006). The value of outdoor learning: Evidence from research in the UK and elsewhere. School Science Review, 87(320), 107-111.

Dursun, Ş. ve Dede, Y. (2004). Öğrencilerin matematikte başarısını etkileyen faktörler matematik öğretmenlerinin görüşleri bakımından. Gazi Üniversitesi Gazi Eğitim Fakültesi Dergisi, 24(2), 217-230.

Even, R. ve Tirosh, D. (2002). Teacher knowledge and understanding of students' mathematical learning. In L. English (Ed.), Handbook of international research in mathematics education. Mahwah, NJ: Laurence Erlbaum.

Gibson, H. L. ve Chase, C. (2002). Longitudinal impact of an inquiry-based science program on middle school students' attitudes toward science. Science Education, 86(5), 693-705.

Gökler, F. (2012). Doğal ortamda yürütülen çevre eğitiminin ortä̈ğretim 9. simıf öğrencilerinin akademik başarılarına etkisi: Ovacık örneği. Yüksek Lisans Tezi, Dokuz Eylül Üniversitesi Eğitim Bilimleri Enstitüsü, İzmir.

Güler, T. (2009). Ekoloji temelli bir çevre eğitiminin öğretmenlerin çevre eğitimine karşı görüşlerine etkileri. Eğitim ve Bilim, 34(151): 30-43.

Howe, C., Nunes, T. ve Bryant, P. (2011). Rational number and proportional reasoning: Using intensive quantities to promote achievement in mathematics and science. International Journal of Science and Mathematics Education, 9(2), 391-417. 
Khishfe, R., ve Abd-El-Khalick, F. (2002). Influence of explicit and reflective versus implicit inquiry-oriented instruction on sixth graders' views of nature of science. Journal of Research in Science Teaching: The Official Journal of the National Association for Research in Science Teaching, 39(7), 551-578.

Kang, N. H. ve Wallace, C. S. (2004). Secondary science teachers' use of laboratory activities: linking epistemological beliefs, goals, and practices. science teacher education. Wiley Interscience, 140-165.

Karadeniz, İ., ve Karadağ, E. (2014). Kırsal bölgelerdeki ortaokul öğrencilerinin matematik kayg1 ve tutumları: korelasyonel bir araştırma. Turkish Journal of Computer and Mathematics Education 5(3), 259-273.

Keklikci, H., ve Yllmazer, Z. (2013). İlköğretim öğrencilerinin matematik korku düzeyleriyle matematik öğretmenlerine yönelik görüşleri arasındaki ilişkinin belirlenmesi. Eğitim ve Öğretim Araştırmaları Dergisi, 2(3), 210-216.

Keleş, Ö., Uzun, N. ve Uzun, F. (2010). Öğretmen adaylarının çevre bilinci, çevresel tutum, düşünce ve davranışlarının doğa eğitimi projesine bağlı değişimi ve kalıcılığının değerlendirilmesi. Elektronik Sosyal Bilimler Dergisi, 9(32), 384-401.

Knox, K. L., Moynihan, J. A., ve Markowitz, D. G. (2003). Evaluation of shortterm impact of a high school summer science program on students' perceived knowledge and skills. Journal of Science Education and Technology, 12(4), 471-478.

Kutluca K., Alpay, N. F. ve Kutluca S. (2015). 8. Sınıf öğrencilerinin matematik kayg1 düzenlerine etki eden faktörlerin incelenmesi. Dicle Üniversitesi Ziya Gökalp Ĕ̆itim Fakültesi, 25, 202-214.

Leblebicioğlu, G., Metin, D., Yardımc1, E., ve Berkyürek, İ. (2011). Teaching the nature of science in the nature: A summer science camp. Elementary Education Online, 10(3), 1037-1055.

Lien, H. A. (2007). The benefits of outdoor education experiences on today's youth. Paper presented at the annual meeting of the North American Association For Environmental Education, Virginia Beach Convention Center, Virginia.

Liu, S. Y. ve Lederman, N. G. (2002). Taiwanese students' views of nature of science. School Science and Mathematics, 102(3), 114-122.

Markowitz, D. G. (2004). Evaluation of the long-term impact of a university high school summer science program on students' interest and perceived abilities in science. Journal of Science Education and Technology, 13(3), 395-407. 
MEB. (2016a). TIMSS 2015 Ulusal matematik ve fen ön raporu 4. ve 8. sinfflar. Ankara: Ölçme, Değerlendirme ve Sınav Hizmetleri Genel Müdürlügü.

MEB. (2016b). PISA 2015 ulusal raporu. Ankara: Ölçme, Değerlendirme ve Sınav Hizmetleri Genel Müdürlügü.

Metin, D. (2009). Yaz bilim kampinda uygulanan yönlendirilmiş araştırma ve bilimin doğası etkinliklerinin ilköğretim 6. ve 7. sinıftaki çocukların bilimin doğası hakkındaki düşüncelerine etkisi. Yüksek Lisans Tezi, Abant İzzet Baysal Üniversitesi Sosyal Bilimler Enstitüsü, Bolu.

Meydan, A., Bozyiğit, R. ve Karakurt, M. (2012). Ekoloji temelli doğa eğitimi projelerinin katılımcı beklentilerini karşılama düzeyleri. Marmara Coğrafya Dergisi, 25, 238-255.

Oğurlu, İ. (2016). Bir doğa eğitim projesinin katılımcı üzerindeki etkilerinin değerlendirilmesi. Batı Anadolu Ĕ̆itim Bilimleri Dergisi, 7(14), 59-101.

Palmberg, E.I. ve Kuru, J. (2000). Outdoor activities as a basis for environmental responsibility. The Journal of Environmental Education, 31(4), 32-6.

Prokop, P., Tuncer, G. ve Kvasničák, R. (2007). Short-term effects of field programme on students' knowledge and attitude toward biology: a Slovak experience. Journal of Science Education and Technology, 16(3), 247-255.

Savaş, E., Taş, S., ve Duru, A. (2010). Factors affecting students' achievement in mathematics. İnönü University Journal of The Faculty Of Education, 11(1), 113-132.

Siew-Eng, L., Kim-Leong, L., ve Siew-Ching, L. (2010). Mathematics camp model for primary school. Procedia-Social and Behavioral Sciences, 8(C), 248-255.

Smith, E.F., Steel, G. ve Gidlow, B. (2010). The temporary community: Student experiences of school-based outdoor education programmes. Journal of Experiential Education, 33(2), 136-150.

Sözer, Y. (2013). Doğada gerçekleştirilen bir matematik yaz kampının lise öğrencileri üzerindeki etkilerinin öğrenci görüşlerine göre incelenmesi. Adnan Menderes Üniversitesi Ĕ̆itim Fakültesi Eğitim Bilimleri Dergisi, 4(2), 1-18.

Şengül, S., ve Cantimer Gerez, G. (2016). Öğrencilerin matematik dersindeki akademik başarı ve başarısızlık nedenlerine yönelik görüşleri. The Journal of Academic Social Science Studies, 51, 383-400.

Tatar, N ve Bağrıyanık, K. E. (2012). Fen ve teknoloji dersi öğretmenlerinin okul dışı eğitime yönelik görüssleri. Illköğretim Online, 11(4), 883-896.

Tekbiyık, A. ve Akdeniz, A. R. (2010). A meta-analytical investigation of the influence of computer assisted instruction on achievement in science. Asia-Pacific Forum on Science Learning and Teaching, 11(2), 1-22. 
Tekbıyık, A., Şeyihoğlu, A., Sezen Vekli, G., ve Birinci-Konur, K. (2013). Aktif öğrenmeye dayalı bir yaz bilim kampının öğrenciler üzerindeki etkilerinin incelenmesi. The Journal of Academic Social Science Studies, 6(1), 1383-1406.

OSYM. (2017). 2017-YGS saylsal bilgiler https://dokuman.osym.gov.tr/pdfdokuman/2017/O SYS/YGS/SAYISAL280 32017.pdf adresinden erişilmiştir.

TUBITAK. (2012). Doğa eğitimi ve bilim okulları yillara göre proje destekleri https://www.tubitak.gov.tr/sites/default/files/4004 web istatistik.pdf adresinden erişilmiştir.

Usta, N. (2014). Bartın ili ortaokullar arası matematik yarışmasına katılan öğrencilere göre matematikte başarılı olmalarını sağlayan faktörler. Bartin University Journal of Faculty of Education, 3(2), 153-173.

Yalçın, H., Ateş-Sönmezoğlu, Ö., Akın, S. ve Sönmezoğlu, S. (2014). Ortaöğretim öğrencilerinin mühendislik bilimlerine yönelik ilgileri. International Journal of Social Science, 27, 135-153. DOI: http://dx.doi.org/10.9761/JASSS2493

Yavuz, M., Gülmez, D. ve Özkaral, T. C. (2016). Meslek lisesi öğrencilerinin bilişsel ve duyuşsal özellikleri. Eğitim ve Bilim, 41(187), 29-44.

Yazkan, E. (2012). Doğal ortamda çevre eğitiminin ortaöğretim 9. sinıf öğrencilerinin başarılarına ve tutumlarına etkisi. Yüksek Lisans Tezi, Dokuz Eylül Üniversitesi Eğitim Bilimleri Enstitüsü, İzmir.

\section{Kaynakça Bilgisi / Citation Information}

Abdioğlu, C., Yılmaz, E. ve Çevik, M. (2020). 8. Sınıf öğrencilerine yönelik Fen-Matematik temalı bilim kampının değerlendirilmesi: "Gelin tanış olalım; Fen ve Matematiği eğlenceli kılalım!" projesi. OPUSUluslararası Toplum Araştırmaları Dergisi , 15(22), 1031-1058. DOI: 10.26466-/opus.635705 